\title{
Yield Responses to Different N-P-K Levels, and Correlations With Foliar Analysis, in Sand-Culture Studies With Corn, Sugarcane, and Cotton ${ }^{1}$
}

\author{
J. A. Bonnet, A. R. Riera, and J. Roldán ${ }^{2}$
}

\section{INTRODUCTION}

A research project to study the nutrient requirements of the principal economic crops of Puerto Rico was started in January 1940. The sandculture method, with ample space and suitable conditions for normal root development of field crops, was used. Inert sand rather than soil was preferred because the sand offered the means to control the initial quantity of nutrients added per treatment to study the minimum to maximum $\mathrm{N}-\mathrm{P}-\mathrm{K}$ levels that may cause deficiency to excess for crop yields.

\section{EQUIPMENT AND METHODS}

Twenty-eight concrete pits were constructed (fig. 1) each about 0.001 acre in area, 10 feet $5 / 8$ inch long, 4 feet 4 inches wide, and from 1 foot 9 inches to 1 foot 11 inches in depth, with drainage outlets. The pits, ditches, and walks occupied the floor space over which a glasshouse (fig. 2), 75 feet $4 \frac{1}{2}$ inches long by 35 feet 2 inches wide, and 10 feet in height at the eaves to 19 feet at top center, was placed. The house was surrounded by a 3 -foot concrete wall except for the double doors at the front and back. The rest of the house was a steel framework covered with glass plates containing movable ventilators at both sides and at the top. The openings were screened with 16-mesh copper wire gauze to protect the crop from insect pests.

Rainwater collected from the roof of the greenhouse and stored in two

1 The results presented in this paper cover the work of a research project included in the 15-year (1940-55) program assigned to the Soils Department. The first 8 years devoted to this project were of an exploratory nature until normal crop growth was obtained. Failures and hopes alternated, then Eureka! The authors wish to express their appreciation to Director Arturo Roque of this Station, who, since he took charge of administrative duties in 1943, strengthened our spiritual faith in the accomplishments of the objectives of this project with stimuli and budget-support. The authors wish also to express their appreciation to Associate Director for Research B. G. Capó, for his guidance and technical advice on the organization, planning, and execution of this project. We wish likewise to thank Ishver S. Bangdiwala, Associate Statistician, Head of the Statistics Department, for his collaboration on the statistical interpretation of the data.

${ }^{2}$ Soil Chemist, Head, Soils Department, Associate Chemist in Charge, Central Analytical Laboratory, and Assistant Chemist, Soils Department, respectively, Agricultural Experiment Station, University of Puerto Rico, Río Piedras, P. R. 


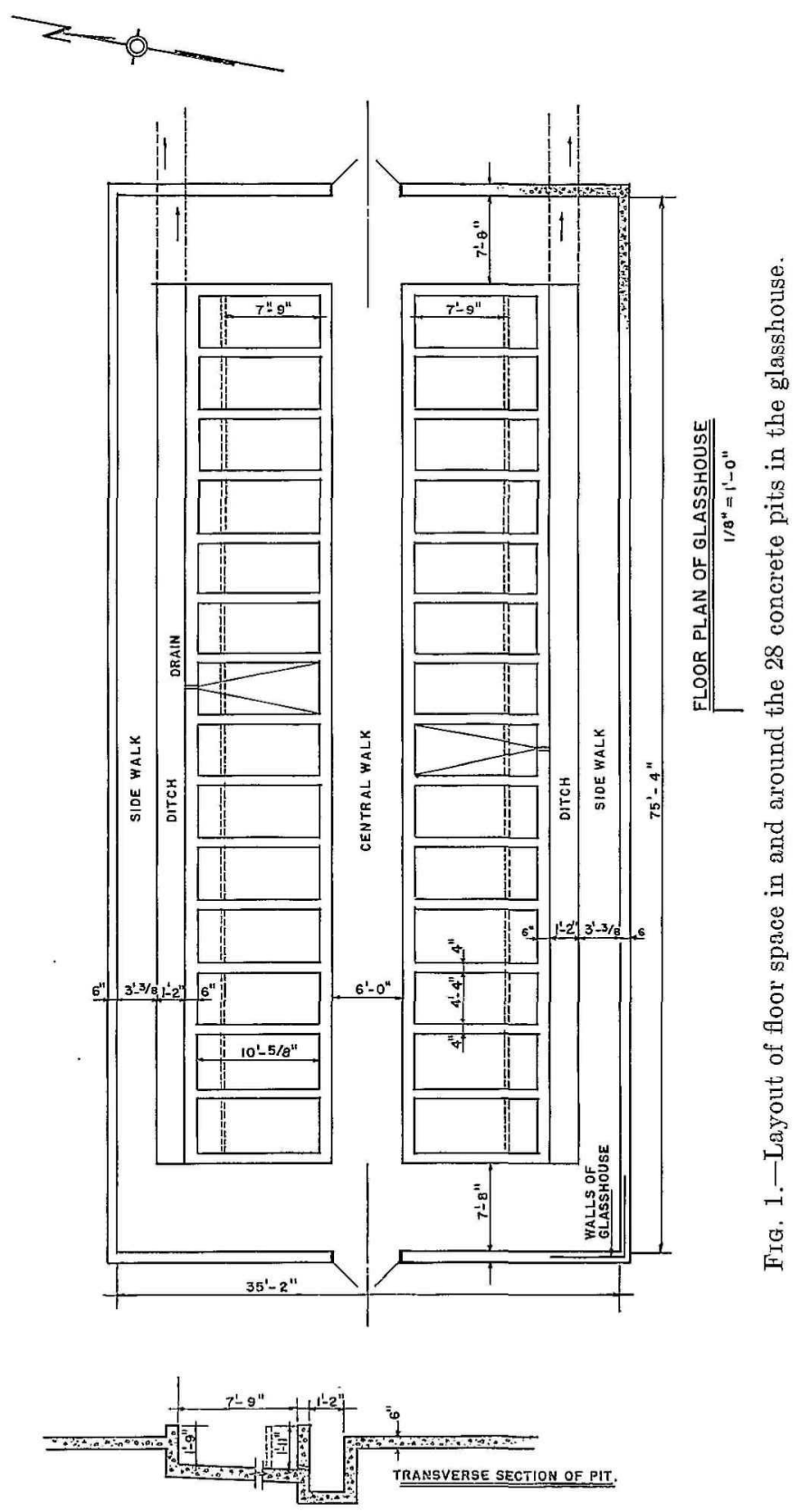


concrete cisterns, each with a capacity of 20,946 gallons, was used for pump irrigation of the crops.

Preliminary pot tests in sand were run with Hegari sorghum, buckwheat, beans, and sugarcane variety P.R. 900, to determine the most favorable nutrient concentration for these crops. Nineteen experiments with crops including sugarcane, beans, corn, sweetpotatoes, and cotton, were per-

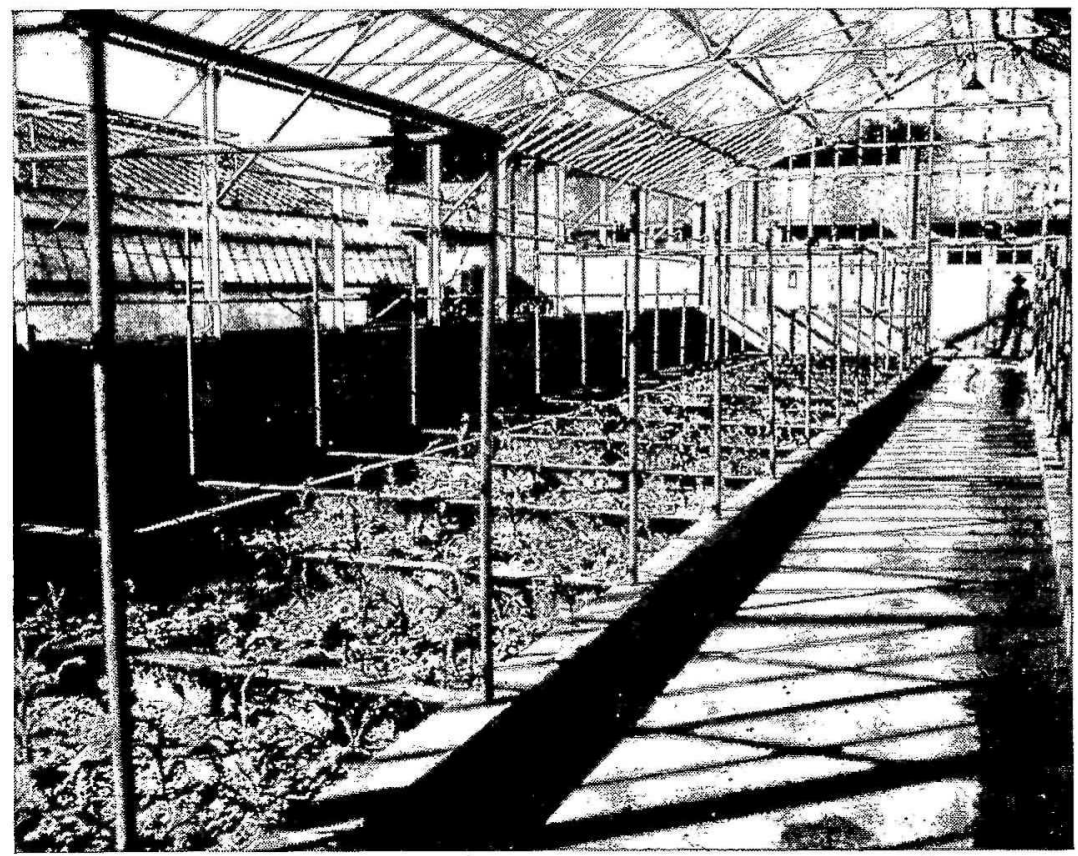

FIG. 2.-View inside the glasshouse when corn plants were growing.

formed in the pits during the 15-year period between August 6, 1940, and July 12, 1955.

Germination and crop growth were abnormal under the glasshouse in the first six experiments, due mainly to uneven sunlight distribution and airventilation, and to high temperatures. Around 2:00 p.m. the temperatures varied 28 to $43^{\circ} \mathrm{C}$. and around 6:00 a.m. from 15 to $17^{\circ} \mathrm{C}$. The coefficients of variability of the crop data were too high, varying from 28 to 40 percent for sugarcane, beans, corn, and sweetpotatoes. To correct for temperature variations the screens and glasses were removed from the greenhouse in July 1946. The seventh and eighth crops then grew normally without the roof and side covers, but the former crop was affected by excess of rainfall and drainage. The length of each of the 28 pits was then reduced to 7 feet 
9 inches, and its area to 0.00077 acre, by constructing a 2 -inch concrete wall (fig. 1) at the drainage outlet (fig. 3). The glasses were replaced in the roof of the greenhouse and the sides were kept open after the eighth crop was harvested in February 1948. Normal growth and yields were obtained in the ninth corn crop and the coefficient of variability of the crop data was reduced to 21.8 percent. It was further reduced to 11.5 percent in the fifteenth crop, which was sugarcane.

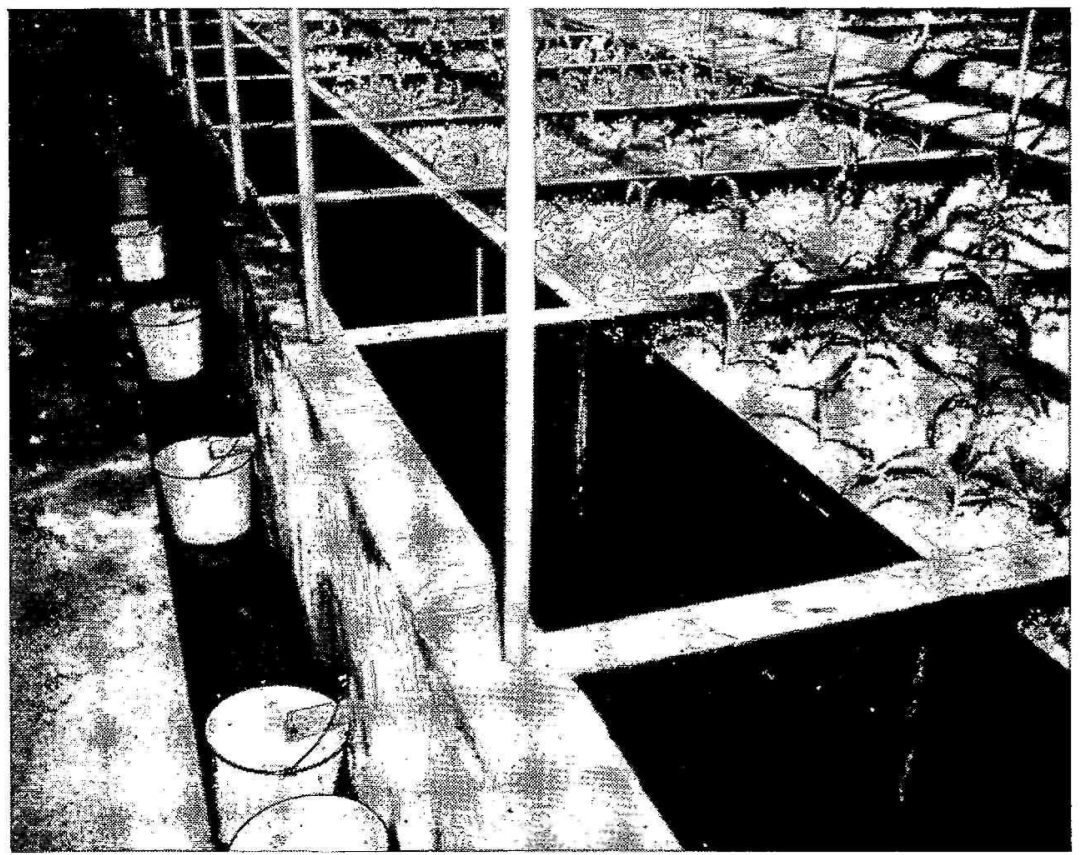

FIG. 3.-Drainage outlets for the pits after construction of the 2-inch concrete wall.

Correlation studies between leaf composition of major nutrients and crop yields were initiated in May 1949 with the tenth crop. By that time the authors $(3)^{3}$ had developed rapid and precise photometric methods for foliar N-P-K analyses, and Capó (5) had developed the arc-tangent formula that expresses the quantitative relationship between yields and composition of the plant as follows:

$$
Y r=A+B \text { arc-tan percent } N u
$$

where $Y r$ is the relative yield, $A$ and $B$ are constants, and arc-tan percent $N u$ is the arc whose tangent is the percentage of the respective nutrient of

${ }^{3}$ Italic numbers in parentheses refer to Literature Cited, p. 184. 
the plant on a dry-matter basis. It was also known that nitrogen was the most important element that limited crop growth in Puerto Rico; that the soils (1) were well supplied with available phosphorus and potassium; that responses to phosphorus (1) were generally limited to short-time crops; and that few responses were obtained with potassium (2) used on long-time crops like sugarcane.

The 6-year (1949-55) data obtained in the last 10 experiments with the crops grown were then used for the correlation studies reported here.

\section{EXPERIMENTAL PROCEDURE}

The strongly acid (pH 4.6), medium-to-fine (table 1), almost pure quartz sand (99 percent $\mathrm{SiO}_{2}$ ) classified as St. Lucie fine sand (7) was used as the growth medium in the pits. This is the same sand used as raw material for glass-manufacturing in Puerto Rico. The sand used for the last two

TABLE 1.-Mechanical composition of the quartz sand used in the experiments

\begin{tabular}{l|r|r}
\hline \multicolumn{1}{c|}{ Classification } & Diameter limits & Percentage \\
\hline & Mfm. & \\
Fine gravel & $2.00-1.00$ & 0.08 \\
Coarse sand & $1.00-.50$ & 5.00 \\
Medium sand & $.50-.25$ & 46.64 \\
Fine sand & $.25-.10$ & 42.65 \\
Very fine sand & $.10-.05$ & 4.79 \\
Silt and clay & Less than- .05 & .84 \\
\hline
\end{tabular}

experiments with cotton was alkaline (pH 8.0) owing to limestone and pieces of broken glass added in the glass factory from which the sand was bought.

A 3-inch layer of 800 pounds of thoroughly washed, noncalcareous, 1/2inch, river gravel was placed on the bottom of each of the 28 pits, over which 3,000 pounds of the sand were spread.

The major elements studied were nitrogen, phosphorus, and potassium, respectively. Seven randomized treatments replicated four times were used. They consisted of variable unit concentrations of the element under study and maximum rates of other two elements. The unit concentration used per pit was 0.03 pound of $\mathrm{N}, 0.015$ pound of $\mathrm{P}_{2} \mathrm{O}_{5}$, and 0.015 pound of $\mathrm{K}_{2} \mathrm{O}$.

Pure salts of the major nutrients required for each experiment were then added at the levels required for the different crops. The nitrogen was applied to the sand in the ratio of 90 parts of nitrate and 10 parts of ammonia, as proposed by Trealease and Trealease (8) for a medium around 
$\mathrm{pH}$ 6.0. The ammonia was added as ammonium sulfate and the nitrate as tetrahydrated calcium nitrate. The phosphorus was applied as monobasic monohydrated calcium phosphate and the potassium as potassium sulfate. The calcium concentration was balanced with gypsum and calcium carbonate. The sulfur concentration was balanced with gypsum. Minor elements were also added in equal quantities to each pit. Examples of the major nutrient levels studied, the kinds and quantities of all salts added, and the concentrations of calcium, sulfur, and minor elements used for the

TABLi 2.-Examples of major nutrient levels and quantities of principal salts added, in grams per pit ${ }^{1}$, in the different treatments

\begin{tabular}{|c|c|c|c|c|c|c|c|c|c|}
\hline \multirow{2}{*}{$\begin{array}{c}\text { Treat- } \\
\text { ment } \\
\text { No. }\end{array}$} & \multicolumn{3}{|c|}{$\begin{array}{l}\text { Nutrient levels² in } \\
\text { units per pit }\end{array}$} & \multirow{2}{*}{$\underset{\left(\mathrm{NH}_{4}\right)_{2}}{\mathrm{SO}_{4}}$} & \multirow{2}{*}{$\underset{4 \mathrm{H}_{2} \mathrm{O}}{\mathrm{Ca}\left(\mathrm{NO}_{2}\right)_{2}}$} & \multirow{2}{*}{$\underset{\mathrm{H}_{2} \mathrm{O}}{\mathrm{Ca}\left(\mathrm{H}_{2} \mathrm{PO}_{4}\right)_{2}}$} & \multirow{2}{*}{$\mathrm{K}_{2} \mathrm{SO}_{4}$} & \multirow{2}{*}{$\mathrm{CaCO}_{3}$} & \multirow{2}{*}{$\mathrm{CaSO}_{4} \cdot 2 \mathrm{H}_{2} \mathrm{O}$} \\
\hline & $\mathrm{N}$ & $\mathrm{P}_{2} \mathrm{O}_{6}$ & $\mathrm{~K}_{2} \mathrm{O}$ & & & & & & \\
\hline 1 & 3 & 15 & 22.2 & 19.25 & 309.68 & 181.23 & 279.45 & 336.66 & 73.28 \\
\hline 2 & 6 & 15 & 22.2 & 38.50 & 619.36 & 181.23 & 279.45 & 220.30 & 47.63 \\
\hline 3 & 9 & 5 & 22.2 & 57.75 & 929.04 & 60.41 & 279.45 & 151.30 & 23.09 \\
\hline 4 & 9 & 10 & 22.2 & 57.75 & 929.04 & 120.82 & 279.45 & 127.32 & 23.09 \\
\hline 5 & 9 & 15 & 7.4 & 57.75 & 929.04 & 181.23 & 93.15 & 28.50 & 151.80 \\
\hline 6 & 9 & 15 & 14.8 & 57.75 & 929.04 & 181.23 & 186.30 & 84.94 & 54.72 \\
\hline 7 & 9 & 15 & 22.2 & 57.75 & 929.04 & 181.23 & 279.45 & 103.32 & 23.09 \\
\hline
\end{tabular}

1 Area of pit $=0.00077 \mathrm{~A}$. Sand per pit $=3,000 \mathrm{lb}$.

${ }^{2}$ Nutrient levels are $0.03,0.015$, and $0.015 \mathrm{lb}$. per unit of $\mathrm{N}, \mathrm{P}_{2} \mathrm{O} 5$, and $\mathrm{K}_{2} \mathrm{O}$, respectively. The $\mathrm{N}$ was added as $\left(\mathrm{NH}_{4}\right)_{2} \mathrm{SO}_{4}$ and $\mathrm{Ca}\left(\mathrm{NO}_{3}\right)_{2} \cdot 4 \mathrm{H}_{2} \mathrm{O}$ in the ratio of 90 parts $\mathrm{NO}_{3}$ to 10 parts $\mathrm{NH}_{3}$. All salts added were e.p. Grams per pit for other nutrients were: $\mathrm{Ca}-233.5, \mathrm{~S}-124.6$ (from main and minor salts), $\mathrm{Mg}-39.9$ as $\mathrm{MgSO}_{4} \cdot 7 \mathrm{H}_{2} \mathrm{O}$, $\mathrm{Fe}-18.2$ as $\mathrm{FeSO}_{4} \cdot 7 \mathrm{H}_{2} \mathrm{O}, \mathrm{Zn}-1.1$ as $\mathrm{ZnSO}_{4} \cdot 7 \mathrm{H}_{2} \mathrm{O}, \mathrm{Cu}-0.4$ as $\mathrm{CuSO}_{4} \cdot 5 \mathrm{H}_{2} \mathrm{O}, \mathrm{Mn}-1.5$ as $\mathrm{MnSO}_{4} \cdot 2 \mathrm{H}_{2} \mathrm{O}, \mathrm{B}-0.2$ as $\mathrm{H}_{3} \mathrm{BO}_{3}$.

sweet corn planted in the eighth experiment are reported in table 2. A similar procedure was followed with the other crops.

The total nitrate salt required for all the treatments in each experiment was dissolved in about 11 . of distilled water and diluted to 21 . in a volumetric flask. Aliquots representing the nitrates required per treatment and per pit were measured respectively, and poured into one sprinkler containing about 81 . of rainwater. The solutions were then sprinkled over the sand in each corresponding pit and the sand was sprinkled again with water.

The quantity of each of the other nutrient salts required per treatment per pit was weighed separately, poured into an 8-1. enameled pail, and dissolved in rainwater. The solution of all the mixed salts was poured uniformly over the sand of each corresponding treatment, the salt residue was again dissolved in water, and the crop was irrigated with two more pails 
filled with water. The pits filled with sand were now ready for planting the crop to be studied.

Corn grains were placed in a porous linen bag attached to a faucet and were soaked overnight under running water. Five corn seed were planted in each of 18 holes, adequately spaced in each pit, but only two plants were left per hole. Sugarcane seed were disinfected before planting by immersion in hot water at $52^{\circ} \mathrm{C}$., for 20 minutes and then were cut crosswise in oneeye node sections. These sections were planted at the rate of one for each of four holes adequately spaced in each pit; extra ones germinated in a separate sand bed supplied material for replanting. The cotton seed were treated with a 1:1 solution of sulfuric acid for 30 minutes and then washed with tapwater. Seven cotton seed were planted in six shallow holes about 1/2-inch deep, adequately spaced in each pit. The germinated plants of corn or of cotton were thinned to two for each hole. Adequate attention was given to pest control. The crops were irrigated when needed after the drainage collected in each pit was poured back over the whole sand surface. Algae growth on the top sand layer was controlled by shallow cultivation with a wooden rake.

Leaf samples of the crops in each pit were taken for analysis at various growth intervals. Composite samples of the outer third portion of the fourth leaves were taken from the corn plants; of the third, fourth, fifth, and sixth leaves from the sugarcane plants; and of the third pair of young leaves from the first crop of cotton plants. The leaf samples were washed with water and prepared and analyzed for total nitrogen, phosphorus, and potassium by the method reported elsewhere $(3,5)$. Data for yield of the crops were recorded at harvesttime.

The correlations between the arc-tangent (5) of the percentage of nitrogen, phosphorus, or potassium in the leaf at various growth intervals of 6 of the 10 crops studied and their relative yields were studied.

\section{RESULTS AND DISCUSSION}

The dates of planting and harvesting for the corn, sugarcane, and cotton, the varieties used, and the crop age at harvesttime for the 10 sand-culture experiments performed.from 1949 to 1955 are reported in table 3. The nutrient levels in units per pit used in those experiments are reported in table 4.

The mean N-P-K contents of the sweet corn leaves at various dayintervals are reported in tables 5,6 , and 7 , respectively. The mean $\mathrm{N}$ and $\mathrm{K}$ contents of the dent corn leaves are reported in tables 8 and 9. The mean $\mathrm{P}$ and $\mathrm{K}$ contents of the sugarcane leaves at various month-intervals are reported in table 10 and those for $\mathrm{N}$ in table 11 . The mean $\mathrm{N}$ contents of the cotton leaves are reported in table 12. 
TABLE 3.-Experiments, varieties, planting and harvesting dates, and age of crops studied in sand cultures from 1949 to 1955

\begin{tabular}{l|l|l|l|c}
\hline $\begin{array}{c}\text { Experiment } \\
\text { No. }\end{array}$ & \multicolumn{1}{|c|}{ Crop and variety } & Planting date & Harvesting date & $\begin{array}{c}\text { Crop age in } \\
\text { months }\end{array}$ \\
\cline { 2 - 2 } 10 & Sweet corn, USDA 34 & Feb. 9, 1949 & May 11, 1949 & 3.1 \\
11 & do. & Aug. 6, 1949 & Oct. 19, 1949 & 2.4 \\
12 & do. & Jan. 20, 1950 & Apr. 21, 1950 & 3.0 \\
13 & do. & July 11, 1950 & Sept. 21, 1950 & 2.3 \\
14 & do. & Nov. 10, 1950 & Jan. 31, 1951 & 2.7 \\
15 & Sugarcane, M. 336 & June 7, 1951 & Feb. 11, 1952 & 8.1 \\
16 & Dent corn, Mayorbela & Apr. 4, 1952 & June 27, 1952 & 2.8 \\
17 & Sugarcane, M. 336 & Sept. 25, 1952 & Dec. 25, 1953 & 15.0 \\
$18,19^{1}$ & Cotton, Sea Island & Aug. 27, 1954 & Feb. 25, July 12, & $6.0,3.6$ \\
& & & 1955 & \\
\hline
\end{tabular}

11 planting and 2 crops.

TABLE 4.-Crops and levels of major nutrients studied in sand cultures from 1949 to 1955

\begin{tabular}{|c|c|c|c|c|}
\hline \multirow{2}{*}{$\begin{array}{l}\text { Experiment } \\
\text { No. }\end{array}$} & \multirow{2}{*}{ Crop } & \multicolumn{3}{|c|}{ Nutrient levels in units 1 per pit of } \\
\hline & & Nitrogen, $N$ & Phosphorus, $\mathrm{P}_{2} \mathrm{O}_{5}$ & Potassium, $\mathrm{K}_{2} \mathrm{O}$ \\
\hline 10. & Sweet corn & $2,4,6$ & $5,10,15$ & $5,10,15$ \\
\hline 11 & do. & $1,2,3,4,5,6,7$ & & 15 \\
\hline 12 & do. & 3.3 & $\begin{array}{l}3,6,9,12,15 \\
18,21\end{array}$ & 15 \\
\hline 13 & do. & 3.3 & 9 & $1,2,3,4,5,6,7$ \\
\hline 14 & do. & 3.3 & 9 & $0, .5,1,2,3,4,5$ \\
\hline 15 & Sugarcane & 6.2 & $1,5,9$ & $1,5,9,13$ \\
\hline 16 & Dent corn & $1.7,2.6,3.4,4.3$ & 9 & $0.5,1.5,2.5,3.5$ \\
\hline 17 & Sugarcane & $\begin{array}{l}1,2.5,4,5.5,7,8.5 \\
10\end{array}$ & 9 & 13 \\
\hline 18,19 & Cotton & $\begin{array}{l}.4, .8,1.2,1.6,2.0 \\
\quad 2.4,2.8\end{array}$ & 4 & 10.3 \\
\hline
\end{tabular}

1 Nutrient levels are equivalent to $0.03 \mathrm{lb} . \mathrm{N}, 0.015 \mathrm{lb} . \mathrm{P}_{2} \mathrm{O}_{5}$, or $0.015 \mathrm{lb} . \mathrm{K}_{2} \mathrm{O}$, per unit, respectively. Nutrient levels in pounds per pit are converted to pounds per acre at a plow depth of $62 \%$ inches (assumed to be equal to 2 million pounds of soil) by dividing by 0.00077 acre, the area of each pit. The quantity of sand in each pit corresponding to an acre-plow depth of $62 / 3$ inches equals $1,540 \mathrm{lb}$. of sand per pit. 
TABLE 5.-Mean nitrogen contents at different crop ages of USDA 34 sweet corn leaves grown at different nitrogen levels added to sand cultures

\begin{tabular}{c|c|c|c|c|c|c|c|c|c}
\hline $\begin{array}{c}\text { Experi- } \\
\text { ment } \\
\text { No. }\end{array}$ & $\begin{array}{c}\text { Units } 1 \\
\text { of N } \\
\text { per pit }\end{array}$ & \multicolumn{7}{c|}{ Percentage of N at ages indicated in days } \\
\cline { 4 - 9 } 11 & 1 & 2.99 & & 2.87 & & 2.10 & & 1.42 & 1.39 \\
10 & 2 & & 3.94 & & 3.82 & & 2.56 & & \\
11 & 2 & 3.37 & & 3.61 & & 2.76 & & 1.69 & 1.69 \\
11 & 3 & 3.44 & & 3.63 & & 3.07 & & 2.00 & 2.03 \\
10 & 4 & & 4.24 & & 4.25 & & 3.46 & & \\
11 & 4 & 3.46 & & 3.80 & & 3.32 & & 2.34 & 2.29 \\
11 & 5 & 3.68 & & 3.77 & & 3.38 & & 2.50 & 2.50 \\
10 & 6 & & 4.23 & & 4.47 & & 3.72 & & \\
11 & 6 & 3.74 & & 3.91 & & 3.41 & & 2.59 & 2.52 \\
11 & 7 & 3.85 & & 4.12 & & 3.52 & & 2.61 & 2.62 \\
\hline
\end{tabular}

11 unit equals $0.03 \mathrm{lb} . \mathrm{N}$.

TABLE 6.-Mean phosphorus contents at different crop ages in USDA 34 sweet corn leaves grown at different phosphorus levels added to sand cultures

\begin{tabular}{|c|c|c|c|c|c|c|c|c|c|c|}
\hline \multirow{2}{*}{$\begin{array}{l}\text { Experiment } \\
\text { No. }\end{array}$} & \multirow{2}{*}{$\begin{array}{l}\text { Units } \mathrm{P}_{2} \mathrm{P}_{5} \\
\text { per pit }\end{array}$} & \multicolumn{9}{|c|}{ Percentage of $\mathrm{P}$ at ages indicated in days } \\
\hline & & 18 & 25 & 30 & 37 & 40 & 45 & 50 & 59 & 65 \\
\hline 12 & 3 & 0.13 & 0.19 & & 0.12 & & 0.17 & & 0.19 & 0.22 \\
\hline 10 & 5 & & & 0.31 & & 0.18 & & 0.12 & & \\
\hline 12 & 6 & .19 & .45 & & .33 & & .33 & & .30 & .31 \\
\hline 12 & 9 & .24 & .64 & & .46 & & .42 & & .35 & .39 \\
\hline 10 & 10 & & & .55 & & .48 & & .29 & & \\
\hline 12 & 12 & .23 & .59 & & .46 & & .44 & & .40 & .41 \\
\hline 10 & 15 & & & .62 & & .47 & & .36 & & \\
\hline 12 & 15 & .26 & .67 & & .49 & & .47 & & .47 & .45 \\
\hline 12 & 18 & .29 & .75 & & .56 & & .51 & & .46 & .46 \\
\hline 12 & 21 & .24 & .70 & & .52 & & .52 & & .50 & .49 \\
\hline
\end{tabular}

11 unit equals $0.015 \mathrm{lb} . \mathrm{P}_{2} \mathrm{O}_{5}$. 
TABLE 7.-Mean potassium contents at different crop ages of USDA 34 sweet corn leaves grown at different potassium levels

added to sand cultures

\begin{tabular}{|c|c|c|c|c|c|c|c|c|c|c|c|}
\hline \multirow{2}{*}{$\begin{array}{l}\text { Experi- } \\
\text { ment No. }\end{array}$} & \multirow{2}{*}{$\begin{array}{c}\text { Units of } \\
\mathrm{K}_{2} \mathrm{O} \text { per pit }\end{array}$} & \multicolumn{10}{|c|}{ Percentage of $\mathrm{K}$ at ages indicated in days } \\
\hline & & 18 & 25 & 30 & 35 & 40 & 45 & 50 & 55 & 65 & 66 \\
\hline 14 & 0 & 1.34 & 2.66 & & 0.76 & & 1.46 & & 1.45 & 1.45 & \\
\hline 14 & 0.5 & 2.50 & 4.28 & & 1.27 & & 1.47 & & 1.37 & 1.60 & \\
\hline 13 & 1 & & & & 2.02 & & 2.60 & & 2.66 & & \\
\hline 14 & 1 & 4.52 & 4.95 & & 1.73 & & 2.04 & & 2.08 & 2.18 & 2.99 \\
\hline 13 & 2 & & & & 2.23 & & 3.25 & & 2.99 & & \\
\hline 14 & 2 & 4.41 & 6.20 & & 2.16 & & 2.07 & & 2.90 & 2.25 & 3.12 \\
\hline 13 & 3 & & & & 2.43 & & 3.73 & & 3.26 & & \\
\hline 14 & 3 & 4.98 & 6.00 & & 2.67 & & 2.47 & & 2.74 & 2.48 & 3.62 \\
\hline 13 & 4 & & • & & 2.45 & & 3.53 & & 3.27 & & \\
\hline 14 & 4 & 6.20 & 6.70 & & 1.94 & & 2.57 & & 3.07 & 2.38 & 4.17 \\
\hline 10 & 5 & & & 4.44 & & 3.08 & & 2.84 & & & \\
\hline 13 & 5 & & & & 2.48 & & 3.67 & & 2.67 & & 3.90 \\
\hline 14 & 5 & 6.40 & 6.71 & & 2.60 & & 3.20 & & 3.15 & 2.67 & \\
\hline 13 & 6 & & & & 2.65 & & 3.91 & & 3.17 & & 4.30 \\
\hline 13 & 7 & & & & 2.69 & & 3.64 & & 3.15 & & 4.48 \\
\hline 10 & 10 & & & 4.36 & & 3.58 & & 2.97 & & & \\
\hline 10 & 15 & & & 4.96 & & 4.25 & & 3.13 & & & \\
\hline
\end{tabular}

11 unit equals $0.015 \mathrm{lb} . \mathrm{K}_{2} \mathrm{O}$.

' TABLE 8.-Mean nitrogen contents at different crop ages of Mayorbela dent corn leaves grown at different nitrogen levels added to sand cultures in experiment 16

\begin{tabular}{c|c|c|c}
\hline \multirow{2}{*}{ Units1 of N per pit } & \multicolumn{3}{|c}{ Percentage of $N$ at ages indicated in days } \\
\cline { 2 - 4 } & 35 & 45 & 55 \\
\hline 1.7 & 4.1 & 2.6 & 1.6 \\
2.6 & 4.1 & 3.0 & 1.5 \\
3.4 & 4.4 & 2.8 & 1.6 \\
4.3 & 4.2 & 3.1 & 1.6 \\
\hline
\end{tabular}

11 unit equals $0.03 \mathrm{lb} . \mathrm{N}$.

TABLE 9.-Mean potassium contents at different crop ages of Mayorbela dent corn leaves grown at different potassium levels added to sand cultures in experiment 16

\begin{tabular}{c|c|c|c}
\hline \multirow{2}{*}{ Units $^{1}$ of $\mathrm{K}_{2} \mathrm{O}$ per pit } & \multicolumn{3}{|c}{ Percentage of $\mathrm{K}$ at ages indicated in days } \\
\cline { 2 - 4 } & 35 & 45 & 55 \\
\hline 0.5 & 1.4 & 1.2 & 1.4 \\
1.5 & 1.7 & 1.6 & 1.3 \\
2.5 & 2.1 & 1.6 & 1.6 \\
3.5 & 2.3 & 1.6 & 1.6 \\
\hline
\end{tabular}

${ }^{1} 1$ unit equals $0.015 \mathrm{lb} . \mathrm{K}_{2} \mathrm{O}$. 
TABLE 10.-Mean phosphorus and potassium contents at different crop ages of $M .336$ sugarcane leaves grown at different phosphorus and potassium

levels added to sand cultures in experiment 15

\begin{tabular}{|c|c|c|c|c|c|c|c|c|c|c|c|c|c|}
\hline \multicolumn{3}{|c|}{ Units' per pit of } & \multicolumn{6}{|c|}{$\begin{array}{c}\text { Percentage of } P \text { at ages indicated in } \\
\text { months }\end{array}$} & \multicolumn{5}{|c|}{$\begin{array}{l}\text { Percentage of } \mathrm{K} \text { at ages indicated } \\
\text { in months }\end{array}$} \\
\hline $\mathrm{N}$ & $\mathrm{P}_{2} \mathrm{O}_{5}$ & $\mathrm{~K}_{2} \mathrm{O}$ & 2 & 3 & 4 & 5 & 6 & 7 & 2 & 3 & 4 & 5 & 7 \\
\hline 6.2 & 1 & 13 & 0.13 & 0.08 & 0.15 & 0.12 & 0.10 & 0.07 & & & & & \\
\hline 6.2 & 5 & 13 & .22 & .09 & .16 & .14 & .11 & .10 & & & & & \\
\hline 6.2 & 9 & 1 & & & & & & & 1.83 & 1.59 & 1.22 & 2.69 & 1.50 \\
\hline 6.2 & 9 & 5 & & & & & & & 2.81 & 2.37 & 2.37 & 2.56 & 1.81 \\
\hline 6.2 & 9 & 9 & & & & & & & 2.60 & 2.78 & 1.98 & 2.21 & 1.77 \\
\hline 6.2 & 9 & 13 & .43 & .19 & .20 & .16 & .12 & .09 & 2.55 & 2.94 & 2.04 & 2.34 & 1.76 \\
\hline
\end{tabular}

${ }^{1} 1$ unit equals $0.03 \mathrm{lb} . \mathrm{N}$, and $0.015 \mathrm{lb} . \mathrm{P}_{2} \mathrm{O}_{5}$ or $\mathrm{K}_{2} \mathrm{O}$.

TABLE 11.-Mean nitrogen contents at different crop ages of $M .396$ sugarcane leaves grown at different nitrogen levels added to

sand cultures in experiment 17

\begin{tabular}{r|c|c|c|c|c|c|c|c|c|c|c|c|c}
\hline $\begin{array}{c}\text { Units } \\
\text { N per pit }\end{array}$ & \multicolumn{10}{c}{ Percentage of $\mathrm{N}$ at ages indicated in months } \\
\cline { 2 - 9 } & 3 & 4 & 5 & 6 & 7 & 8 & 9 & 10 & 11 & 12 & 13 & 14 & 15 \\
\hline 1.0 & 2.93 & 1.33 & 1.28 & 1.16 & 1.09 & 1.27 & 1.43 & 1.43 & 1.40 & 1.12 & 1.30 & 1.01 & 1.18 \\
2.5 & 3.07 & 1.95 & 1.74 & 1.52 & 1.16 & 1.22 & 1.51 & 1.49 & 1.37 & 1.14 & 1.39 & 1.19 & 1.15 \\
4.0 & 2.96 & 2.03 & 1.88 & 1.54 & 1.27 & 1.39 & 1.45 & 1.31 & 1.39 & .99 & 1.11 & .95 & 1.07 \\
5.5 & 2.92 & 1.91 & 1.90 & 1.82 & 1.53 & 1.43 & 1.71 & 1.51 & 1.38 & 1.11 & 1.25 & 1.08 & 1.03 \\
7.0 & 3.03 & 1.99 & 1.98 & 1.69 & 1.70 & 1.60 & 1.78 & 1.61 & 1.39 & 1.20 & 1.32 & 1.19 & 1.31 \\
8.5 & 3.00 & 2.12 & 2.05 & 1.92 & 1.69 & 1.75 & 1.79 & 1.64 & 1.53 & 1.25 & 1.39 & 1.29 & 1.20 \\
10.0 & 3.10 & 2.14 & 2.00 & 1.91 & 1.82 & 1.80 & 1.92 & 1.68 & 1.65 & 1.35 & 1.47 & 1.28 & 1.29 \\
\hline
\end{tabular}

11 unit equals $0.03 \mathrm{lb} . \mathrm{N}$.

TABLE 12,-Mean nitrogen contents at different crop ages of Sea Island cotton leaves grown at different nitrogen levels added to sand cultures in experiment 18

\begin{tabular}{|c|c|c|c|c|c|c|c|}
\hline \multicolumn{3}{|c|}{ Units 1 per pit of } & \multicolumn{5}{|c|}{ Percentage of $N$ at ages indicated in months } \\
\hline $\mathrm{N}$ & $\mathrm{P}_{2} \mathrm{O}_{5}$ & $\mathrm{~K}_{2} \mathrm{O}$ & 1 & 2 & 3 & 4 & 5 \\
\hline 0.4 & 4 & 10.3 & 3.27 & 2.55 & 2.29 & 2.14 & 1.66 \\
\hline .8 & 4 & 10.3 & 3.60 & 3.71 & 2.92 & 2.13 & 1.73 \\
\hline 1.2 & 4 & 10.3 & 3.48 & 3.07 & 2.95 & 2.46 & 2.05 \\
\hline 1.6 & 4 & 10.3 & 3.88 & 4.28 & 3.10 & 2.27 & 1.67 \\
\hline 2.0 & 4 & 10.3 & 4.00 & 4.04 & 3.25 & 2.12 & 1.72 \\
\hline 2.4 & 4 & 10.3 & 3.90 & 3.61 & 3.88 & 3.31 & 2.53 \\
\hline 2.8 & 4 & 10.3 & 4.08 & 4.24 & 3.60 & 2.79 & 2.08 \\
\hline
\end{tabular}

11 unit equals $0.03 \mathrm{lb} . \mathrm{N}$, and $0.015 \mathrm{lb} . \mathrm{P}_{2} \mathrm{O}_{5}$ or $\mathrm{K}_{2} \mathrm{O}$. 
TABLE 13.-Mean yields of USDA-34 sweet corn grown at different $N-P-K$ levels added to sand cultures, and least significant differences between treatment means

\begin{tabular}{|c|c|c|c|c|c|}
\hline \multirow{2}{*}{ Experiment No. } & \multirow{2}{*}{ Treatment No. } & \multicolumn{3}{|c|}{ Units 1 per pit } & \multirow{2}{*}{$\begin{array}{l}\text { Mean crop yield of } 4 \\
\text { replicates in hundredweights } \\
\text { of grain per acre }\end{array}$} \\
\hline & & $N$ & $\mathrm{P}_{2} \mathrm{O}_{5}$ & $\mathrm{~K}_{2} \mathrm{O}$ & \\
\hline \multirow[t]{7}{*}{10} & 1 & 2 & 15 & 15 & 6.5 \\
\hline & 2 & 4 & 15 & 15 & 17.9 \\
\hline & 3 & 6 & 5 & 15 & 10.4 \\
\hline & 4 & 6 & 10 & 15 & 31.0 \\
\hline & 5 & 6 & 15 & 5 & 31.6 \\
\hline & 6 & 6 & 15 & 10 & 28.8 \\
\hline & 7 & 6 & 15 & 15 & 28.6 \\
\hline \multirow{2}{*}{\multicolumn{5}{|c|}{$\begin{array}{r}\text { L.S.D. between treatment means at: } 1 \text {-percent point } \\
5 \text {-percent point }\end{array}$}} & 3.8 \\
\hline & & & & & 2.7 \\
\hline \multirow[t]{7}{*}{11} & 1 & 1 & 15 & 15 & 1.7 \\
\hline & 2 & 2 & 15 & 15 & 7.0 \\
\hline & 3 & 3 & 15 & 15 & 4.4 \\
\hline & 4 & 4 & 15 & 15 & 15.4 \\
\hline & 5 & 5 & 15 & 15 & 15.3 \\
\hline & 6 & 6 & 15 & 15 & 15.1 \\
\hline & 7 & 7 & 15 & 15 & 12.6 \\
\hline \multirow{2}{*}{\multicolumn{5}{|c|}{$\begin{array}{r}\text { L.S.D. between treatment means at: } 1 \text {-percent point } \\
\text { 5-percent point }\end{array}$}} & 2.7 \\
\hline & & & & & 2.0 \\
\hline \multirow[t]{7}{*}{12} & 1 & 3.3 & 3 & 15 & 2.0 \\
\hline & 2 & 3.3 & 6 & 15 & 18.4 \\
\hline & 3 & 3.3 & 9 & 15 & 21.4 \\
\hline & 4 & 3.3 & 12 & 15 & 20.9 \\
\hline & 5 & 3.3 & 15 & 15 & 20.7 \\
\hline & 6 & 3.3 & 18 & 15 & 20.6 \\
\hline & 7 & 3.3 & 21 & 15 & 20.8 \\
\hline \multicolumn{5}{|c|}{$\begin{array}{r}\text { L.S.D. between treatment means at: } 1 \text {-percent point } \\
\text { 5-percent point }\end{array}$} & 5.4 \\
\hline \multirow[t]{7}{*}{13} & 1 & 3.3 & 9 & 1 & 9.8 \\
\hline & 2 & 3.3 & 9 & 2 & 10.2 \\
\hline & 3 & 3.3 & 9 & 3 & 9.5 \\
\hline & 4 & 3.3 & 9 & 4 & 10.4 \\
\hline & 5 & 3.3 & 9 & 5 & 10.4 \\
\hline & 6 & 3.3 & 9 & 6 & 9.3 \\
\hline & 7 & 3.3 & 9 & 7 & 12.4 \\
\hline \multicolumn{5}{|c|}{$\begin{array}{r}\text { L.S.D. between treatment means at: } 1 \text {-percent point } \\
\text { 5-percent point }\end{array}$} & 3.28 \\
\hline
\end{tabular}




\begin{tabular}{|c|c|c|c|c|c|}
\hline \multirow{2}{*}{ Experiment No. } & \multirow{2}{*}{ Treatment No. } & \multicolumn{3}{|c|}{ Units per pit } & \multirow{2}{*}{$\begin{array}{l}\text { Mean crop yield of } 4 \\
\text { replicates in hundredweights } \\
\text { of grain per acre }\end{array}$} \\
\hline & & $\mathbf{N}$ & $\mathrm{P}_{2} \mathrm{O}_{5}$ & $\mathrm{~K}_{2} \mathrm{O}$ & \\
\hline \multirow[t]{7}{*}{14} & 1 & 3.3 & 9 & 0 & 1.8 \\
\hline & 2 & 3.3 & 9 & 0.5 & 6.0 \\
\hline & 3 & 3.3 & 9 & 1 & 7.3 \\
\hline & 4 & 3.3 & 9 & 2 & 9.4 \\
\hline & 5 & 3.3 & 9 & 3 & 8.1 \\
\hline & 6 & 3.3 & 9 & 4 & 8.0 \\
\hline & 7 & 3.3 & 9 & 5 & 8.2 \\
\hline \multicolumn{5}{|c|}{$\begin{array}{r}\text { L.S.D. between treatment means at: } 1 \text {-percent point } \\
\text { 5-percent point }\end{array}$} & $\begin{array}{l}2.5 \\
1.9\end{array}$ \\
\hline
\end{tabular}

11 unit equals $0.03 \mathrm{lb} . \mathrm{N}$, and $0.015 \mathrm{lb} . \mathrm{P}_{2} \mathrm{O}_{5}$ or $\mathrm{K}_{2} \mathrm{O}$.

TABLE 14.-Mean yields of Mayorbela dent corn grown at different $N-P-K$ levels added to sand cultures, and least significant differences between treatment means in experiment 16

\begin{tabular}{c|c|c|c|c}
\hline \multirow{2}{*}{ Treatment No. } & \multicolumn{3}{|c|}{ Units' per pit } & $\begin{array}{c}\text { Mean crop yield of 4 } \\
\text { replicates in hundredweight } \\
\text { of grain per acre }\end{array}$ \\
\cline { 2 - 4 } & $\mathrm{N}$ & $\mathrm{P}_{2} \mathrm{O}_{6}$ & $\mathrm{~K}_{2} \mathrm{O}$ & 11.2 \\
& 1.7 & 9 & 3.5 & 15.7 \\
2 & 2.6 & 9 & 3.5 & 18.6 \\
3 & 3.4 & 9 & 3.5 & 8.8 \\
4 & 4.3 & 9 & 0.5 & 14.3 \\
5 & 4.3 & 9 & 1.5 & 18.7 \\
6 & 4.3 & 9 & 2.5 & 21.1 \\
7 & 4.3 & 9 & 3.5 & 4.6 \\
\hline \hline
\end{tabular}

${ }_{1} 1$ unit equals $0.03 \mathrm{lb} . \mathrm{N}$, and $0.015 \mathrm{lb} . \mathrm{P}_{2} \mathrm{O}_{5}$ or $\mathrm{K}_{2} \mathrm{O}$.

The mean yields of sweet corn, dent corn, sugarcane, and cotton are reported in tables $13,14,15$, and 16. The sugarcane data include yields of cane, sugar, trash, and roots, and the percentage of sugar in cane. The cotton data include yields of lint and seed. The least significant differences between mean yields of the different nitrogen treatments are also reported in the appropriate tables.

There were highly significant yield responses of corn to nitrogen, phosphorus, and potassium (tables 13, 14). There were highly significant responses of sugarcane in the yields of cane, sugar, trash, and roots, when either $\mathrm{N}$ or $\mathrm{P}$ was added (table 15). There were highly significant yield 
responses of cotton in yields of lint and seed when nitrogen was added (table 16).

Highly significant correlations (table 17) were obtained between relative yields of corn and respective arc-tangent $\mathrm{N}$ contents in their leaves for

TABLE 15.-Mean cane, sugar, trash, and root yields, and percentage of sugar of $M$. 336 sugarcane grown at different $N-P-K$ levels added to sand cultures, and least significant differences between treatment means

\begin{tabular}{|c|c|c|c|c|c|c|c|c|c|}
\hline \multirow{2}{*}{$\begin{array}{l}\text { Experiment } \\
\text { No. }\end{array}$} & \multirow{2}{*}{$\begin{array}{l}\text { Treatment } \\
\text { No. }\end{array}$} & \multicolumn{3}{|c|}{ Units $^{1}$ per pit } & \multicolumn{4}{|c|}{ Mean crop yield in tons per acre } & \multirow{2}{*}{$\begin{array}{l}\text { Percentage } \\
\text { of sugar in } \\
\text { cane }\end{array}$} \\
\hline & & $\mathrm{N}$ & $\mathrm{P}_{2} \mathrm{O}_{5}$ & $\mathrm{~K}_{2} \mathrm{O}$ & Cane & Sugat & Trash & Roots & \\
\hline \multirow[t]{6}{*}{15} & 1 & 6.2 & 1 & 13 & 3.5 & 0.29 & 5.4 & 1.3 & 7.8 \\
\hline & 2 & 6.2 & 5 & 13 & 14.0 & 1.46 & 10.6 & 2.9 & 10.4 \\
\hline & 3 & 6.2 & 9 & 1 & 13.3 & .77 & 10.7 & 2.2 & 5.5 \\
\hline & 4 & 6.2 & 9 & 5 & 18.3 & 1.35 & 13.1 & 3.1 & 7.1 \\
\hline & 5 & 6.2 & 9 & 9 & 18.2 & 1.46 & 11.7 & 3.0 & 8.0 \\
\hline & 6 & 6.2 & 9 & 13 & 18.5 & 1.60 & 12.3 & 2.6 & 8.5 \\
\hline \multicolumn{5}{|c|}{ L.S.D. between treatment means at: } & 8.2 & 0.93 & 3.9 & 1.2 & 3.9 \\
\hline \multicolumn{5}{|c|}{5 -percent point } & 5.9 & .67 & 2.8 & .9 & 2.8 \\
\hline \multirow[t]{7}{*}{17} & 1 & 1.0 & 9 & 13 & 20.0 & 2.1 & 5.8 & 4.0 & 10.3 \\
\hline & 2 & 2.5 & 9 & 13 & 27.8 & 3.1 & 8.1 & 5.9 & 11.2 \\
\hline & 3 & 4.0 & 9 & 13 & 50.1 & 5.9 & 11.9 & 8.4 & 11.9 \\
\hline & 4 & 5.5 & 9 & 13 & 62.8 & 8.3 & 13.8 & 7.5 & 13.1 \\
\hline & 5 & 7.0 & 9 & 13 & 73.8 & 10.0 & 16.1 & 8.1 & 13.7 \\
\hline & 6 & 8.5 & 9 & 13 & 81.3 & 11.0 & 19.0 & 7.7 & 13.5 \\
\hline & 7 & 10.0 & 9 & 13 & 83.1 & 10.7 & 19.0 & 7.3 & 12.9 \\
\hline \multicolumn{5}{|c|}{ L.S.D. between treatment means at: } & & & & & \\
\hline \multirow[t]{2}{*}{. } & \multicolumn{4}{|c|}{ 1-percent point } & 13.2 & 1.4 & 4.0 & 3.3 & 1.9 \\
\hline & \multicolumn{4}{|c|}{5 -percent point } & 9.6 & 1.0 & 2.9 & 2.4 & 1.4 \\
\hline
\end{tabular}

11 unit equals $0.03 \mathrm{lb}$. of $\mathrm{N}$ and $0.015 \mathrm{lb}$. of $\mathrm{P}_{2} \mathrm{O}_{5}$ or $\mathrm{K}_{2} \mathrm{O}$.

ages varying from 25 to 65 days, also for the arc-tangent $\mathrm{P}$ and $\mathrm{K}$ contents from 18 to 65 days.

Significant correlations (table 18) were also obtained between the relative yields of sugarcane and arc-tangent $\mathrm{N}$ contents at the age of 4 months, and highly significant correlations at the age of 5 months. The correlation at different ages between nitrogen and green- and dry-matter contents of leaves and yields of sugarcane in this experiment have already been published (4). Highly significant correlations were obtained also (table 18) for arc-tangent phosphorus contents when the sugarcane plants were 3 or 
TABLE 16.-Mean yields of Sea Island cotton grown at different nitrogen levels added to sand cultures, and least significant differences between treatment means

\begin{tabular}{|c|c|c|c|c|c|c|c|}
\hline \multirow{2}{*}{ Experiment No. } & \multirow{2}{*}{ Treatment No. } & \multicolumn{3}{|c|}{ Units ${ }^{1}$ per pit } & \multicolumn{3}{|c|}{$\begin{array}{l}\text { Mean crop yields in hundred- } \\
\text { weights per acre }\end{array}$} \\
\hline & & $\mathrm{N}$ & $\mathrm{P}_{2} \mathrm{O}_{5}$ & $\mathrm{~K}_{2} \mathrm{O}$ & $\begin{array}{c}\text { Lint } \\
\text { Cotton }\end{array}$ & $\begin{array}{c}\text { Cotton } \\
\text { with seed }\end{array}$ & Seed \\
\hline 18 & $\begin{array}{l}1 \\
2 \\
3 \\
4 \\
5 \\
6 \\
7\end{array}$ & $\begin{array}{r}0.4 \\
.8 \\
1.2 \\
1.6 \\
2.0 \\
2.4 \\
2.8\end{array}$ & $\begin{array}{l}4 \\
4 \\
4 \\
4 \\
4 \\
4 \\
4\end{array}$ & $\begin{array}{l}10.3 \\
10.3 \\
10.3 \\
10.3 \\
10.3 \\
10.3 \\
10.3\end{array}$ & $\begin{array}{l}.62 \\
3.01 \\
1.88 \\
5.58 \\
4.75 \\
4.32 \\
6.57\end{array}$ & $\begin{array}{r}1.74 \\
8.46 \\
5.46 \\
14.62 \\
12.46 \\
11.37 \\
17.35\end{array}$ & $\begin{array}{r}1.12 \\
5.45 \\
3.57 \\
9.04 \\
7.69 \\
7.05 \\
10.74\end{array}$ \\
\hline \multicolumn{5}{|c|}{$\begin{array}{r}\text { L.S.D. between treatment means at: } 1 \text {-percent point } \\
5 \text {-percent point }\end{array}$} & $\begin{array}{l}4.69 \\
3.42\end{array}$ & $\begin{array}{r}12.22 \\
8.92\end{array}$ & $\begin{array}{l}7.54 \\
5.50\end{array}$ \\
\hline 19 & $\begin{array}{l}1 \\
2 \\
3 \\
4 \\
5 \\
6 \\
7\end{array}$ & $\begin{array}{r}0.4 \\
.8 \\
1.2 \\
1.6 \\
2.0 \\
2.4 \\
2.8\end{array}$ & $\begin{array}{l}4 \\
4 \\
4 \\
4 \\
4 \\
4 \\
4\end{array}$ & $\begin{array}{l}10.3 \\
10.3 \\
10.3 \\
10.3 \\
10.3 \\
10.3 \\
10.3\end{array}$ & $\begin{array}{l}1.35 \\
1.22 \\
1.36 \\
1.51 \\
1.29 \\
2.71 \\
2.11\end{array}$ & $\begin{array}{l}3.20 \\
2.99 \\
3.42 \\
3.71 \\
3.15 \\
6.76 \\
5.30\end{array}$ & $\begin{array}{l}1.85 \\
1.77 \\
2.06 \\
2.20 \\
1.85 \\
4.05 \\
3.19\end{array}$ \\
\hline \multicolumn{5}{|c|}{$\begin{array}{r}\text { L.S.D. between treatment means at: } 1 \text {-percent point } \\
\text { 5-percent point }\end{array}$} & $\begin{array}{l}1.98 \\
1.45\end{array}$ & $\begin{array}{l}4.80 \\
3.51\end{array}$ & $\begin{array}{l}3.15 \\
2.30\end{array}$ \\
\hline
\end{tabular}

11 unit equals $0.03 \mathrm{Ib} . \mathrm{N}$, and $0.015 \mathrm{lb} . \mathrm{P}_{2} \mathrm{O}_{5}$ or $\mathrm{K}_{2} \mathrm{O}$.

TABLE 17.-Significance $e^{1}$ of correlations between relative yields of sweet corn and the arc-tangent of $N-P-K$ contents of its leaves for different crop ages

\begin{tabular}{|c|c|c|c|c|c|c|c|c|c|c|c|c|}
\hline \multirow{2}{*}{$\begin{array}{c}\text { Experi- } \\
\text { ment } \\
\text { No. }\end{array}$} & \multirow{2}{*}{$\begin{array}{l}\text { Arc- } \\
\text { tangent } \\
\text { of- }\end{array}$} & \multicolumn{11}{|c|}{ Significance at crop ages indicated in days } \\
\hline & & 18 & 25 & 30 & 35 & 37 & 40 & 45 & 50 & 55 & 59 & 65 \\
\hline 10 & $\begin{array}{l}\mathrm{N} \\
\mathrm{P} \\
\mathrm{K}\end{array}$ & & & $\underset{* \text { N.S. }}{\text { N.S. }}$ & & & $\begin{array}{c}* * \\
* * \\
N\end{array}$ & & $\begin{array}{l}* * \\
* \\
*\end{array}$ & & & \\
\hline 11 & $\vec{N}$ & & $* *$ & & $* *$ & & & $* *$ & & $* *$ & & $* *$ \\
\hline 12 & $\mathbf{P}$ & $* *$ & ** & & & $* *$ & & $* *$ & & & $*$ & $* *$ \\
\hline 14 & $\mathrm{~K}$ & ** & ** & & ** & & & ** & & $* *$ & & ** \\
\hline
\end{tabular}

1 N.S.-nonsignificant; **-significant at 1-percent point; *-significant at 5-percent point. 
4 months old, but no significant correlations for arc-tangent potassium contents were obtained in this experiment.

TABIE 18.-Significance ${ }^{1}$ of correlations between relative yields of sugarcane and the arc-tangent of the $N-P-K$ contents at different crop ages

\begin{tabular}{c|c|c|c|c}
\hline \multirow{2}{*}{$\begin{array}{c}\text { Experiment } \\
\text { No. }\end{array}$} & Correlation between relative yields and & \multicolumn{2}{|c}{ Significance at crop ages indicated in months } \\
\cline { 3 - 4 } & & 3 & 4 & 5 \\
\hline 15 & Arc-tangent $\mathrm{P}$ & $* *$ & $* *$ & \\
15 & Arc-tangent $\mathrm{K}$ & N.S. & N.S. & $*$ \\
17 & Arc-tangent N & N.S. & $*$ & $*$ \\
\hline
\end{tabular}

${ }^{1}$ N.S.-nonsignificant; **-significant at 1-percent point; *-significant at 5-percent point.

\section{SUMMMARY}

The layout for 28 concrete pits is described herein where sand-culture and irrigation studies under cover have been carried in Puerto Rico since 1940 with certain crops: Sugarcane, beans, corn, sweetpotatoes, and cotton. The data for 10 experiments performed with sweet corn, dent corn, sugarcane, and cotton are reported. These data included N-P-K contents of the respective leaves at different crop ages and yields obtained by varying the $\mathrm{N}$ or $\mathrm{P}$ or $\mathrm{K}$ levels from deficient to sufficient values, but keeping other major and minor nutrients constant.

These experiments were important in showing that foliar contents of the major nutrients at specific crop ages can be used to predict or correlate with relative yield values. These correlations are not generally obtained with phosphorous and potassium in field experiments because the initial available phosphorus and potassium contents of the soil are usually high.

\section{RESUMEN}

Este trabajo ilustra la manera usada en Puerto Rico, desde el 1940, de preparar recipientes de concreto para llevar a cabo estudios con diferentes cosechas, tales como caña de azúcar, habichuelas, maíz, batatas, y algodón bajo techo y con riego. Se informan, también, los resultados de 10 experimentos hechos en estos recipientes con maíz, caña de azúcar y algodón.

Los datos obtenidos de estos experimentos incluyen los contenidos de N-P-K de las hojas de las mencionadas cosechas a distintas edades y los rendimientos alcanzados con niveles variables de $\mathrm{N}$, de $\mathrm{P}$, o de $\mathrm{K}$, empezando con una cantidad mínima deficiente hasta la máxima suficiente, pero en todos los casos añadiendo cantidades suficientes de todos los otros nutrientes. 
Estos experimentos han sido de gran utilidad para demostrar que los análisis foliares en cuanto a N-P-K, a una edad específica, pueden predecir los rendimaientos relativos o estar relacionados con los mismos. Estas correlaciones no se obtienen regularmente de los datos de los experimentos de campo, porque generalmente los contenidos de $\mathrm{P}$ y $\mathrm{K}$ en los suelos de Puerto Rico son altos.

\section{LITERATURE CITED}

1. Bonnet, J. A., Chemical data of Puerto Rico soils, correlation of data for humid and arid areas; field response of crops to available phosphorus and potash in soils, Agr. Exp. Sta. P. R., Res. Bul. 1, 53 pp., Apr. 1941.

2. $\longrightarrow$ Potassium content of Puerto Rican soils as related to sugarcane growing, $J$. Agr. Univ. P. R. 37 (3) 183-94, 1953.

3. Bonnet, J. A., Riera, A., Roldán, J., y Ascorbe, F. J., Métodos para determinaciones de nitrógeno, fósforo y potasio total usados para análisis foliar en el Departamento de Suelos de la Estación Experimental Agrícola de la Universidad de Puerto Rico: A mimeographed paper in Spanish presented to the Annual Meeting of the Association of Sugar Cane Technologists, 12 pp., Jan. 20, 1951.

4. Bonnet, J. A., Riera, A. R., and Roldán, J., Correlation at different ages between nitrogen, green- and dry-matter contents of leaves, and yield of sugarcane grown in sand culture, J. Agr. Univ. P.R. 40 (2) 101-9, 1956.

5. Capó, B. G., and Samuels, G., The development of a mathematical concept to interpret the relation between plant composition and crop yield, $J$. Agr. Univ. P. R. 37 (4) 249-64, 1955.

6. Riera, A., Part II: The chemical analysis of sugarcane leaf samples, Bul. 123, Agr. Exp. Sta. Univ. P. R. 23-32, Feb. 1955.

7. Roberts, R. C., and party, Soil Survey Puerto Rico, p. 311, USDA Bur. of Plant Ind. in Co-op with Univ. P. R. Agr. Exp. Sta., Series 1936, No. 8, 503 pp., issued Jan. 1942.

8. Trealease, Sam F., and Trealease, Helen M., Changes in hydrogen-ion concentration of culture solutions containing nitrate and ammonium nitrogen, Amer. J. Bot. 22 (5) 520-42, 1935. 